\title{
Chromosome polymorphism of heterochromatin and nucleolar regions in two populations of the fish Astyanax bockmanni (Teleostei: Characiformes)
}

\author{
Diogo Teruo Hashimoto and Fábio Porto-Foresti
}

\begin{abstract}
Karyotype and other chromosomal markers as revealed by C-banding and silver (Ag) impregnation in two Astyanax bockmanni populations (Barra Seca Stream and Campo Novo River) were examined. The diploid chromosome number $2 \mathrm{n}=$ 50 and nearly identical karyotypes were documented. C-banding revealed heterochromatic blocks on the terminal regions of some chromosomes, with high frequencies of polymorphisms. The Ag-impregnation showed that the nucleolus organizer regions (NORs) varied in number, location and organization. Astyanax bockmanni revealed chromosome characteristics similar those of the species complex "A. scabripinnis". Mechanisms that may be responsible for the high degree of polymorphism are discussed.
\end{abstract}

Cariótipo e outros marcadores cromossômicos revelados pelo bandamento $\mathrm{C}$ e impregnação da prata (Ag) em duas populações de Astyanax bockmanni (córrego Barra Seca e rio Campo Novo) foram examinados. O número cromossômico diploide $2 \mathrm{n}=50$ e cariótipo quase idênticos são documentados. Bandamento $\mathrm{C}$ revelou blocos heterocromáticos na região terminal de alguns cromossomos, com um elevado nível de polimorfismos. A impregnação da prata mostrou variabilidade do número, posição e organização para as regiões organizadoras de nucléolo (RONs). Astyanax bockmanni revelou características cromossômicas similares ao complexo "A. scabripinnis" e os mecanismos responsáveis pelo alto nível do polimorfismo foram discutidos.

Key words: Fish cytogenetics, Chromosomal rearrangements, Karyotype differentiation.

\section{Introduction}

The family Characidae, order Characiformes, is one of the most numerous and diverse families of freshwater fishes in South America (Nelson, 2006), consisting of approximately 597 recognized species (Buckup et al., 2007). The genus Astyanax, a speciose group of Neotropical characids, comprises about 86 valid species (Lima et al., 2003) that occur in diverse habitats within freshwater drainages from the southern United States to central Argentina.

According to Mirande (2009), the nominal species currently assigned to Astyanax represent a nonmonophyletic assemblage. Consequently, cytogenetic studies have been valuable for better systematic analysis of Astyanax, especially for species that need more than morphological criteria for their characterization. An example is Astyanax scabripinnis, which was first characterized as a "species complex" by Moreira-Filho \& Bertollo (1991) based on chromosomal and morphological characters. It currently contains 15 valid species (Bertaco \& Lucena, 2006).
Astyanax bockmanni is broadly distributed in tributaries from the upper Paraná River system of central, southeastern, and southern Brazil (Vari \& Castro, 2007). According to these authors, even though the lack of a comprehensive treatment of the Astyanax species complicates the diagnosis of $A$. bockmanni from all congeners, this species can be distinguished from its congeners by a combination of diagnostic characters that allow the elimination of $A$. bockmanni from the complex "A. scabripinnis" (Eigenmann, 1921; Bertaco \& Lucena, 2006).

Several species of the genus Astyanax have already been studied genetically, primarily cytogenetically (e.g., MoreiraFilho \& Bertollo, 1991; Artoni et al., 2006; Hashimoto et al., 2008; Vicari et al., 2008a). The first cytogenetic study of $A$. bockmanni was carried out by Kavalco et al. (2009) who described the karyotypes of two populations originating from the Paranapanema River basin. The karyotype of this species differs from other Astyanax species such as A. scabripinnis and $A$. fasciatus for which intensive chromosomal polymorphism was reported (Moreira-Filho \& Bertollo, 1991; Abel et al., 2006; Artoni et al., 2006).

Departamento de Ciências Biológicas, Faculdade de Ciências, Universidade Estadual Paulista (UNESP), Campus de Bauru. 17033-360 Bauru, SP, Brazil. diogo@fc.unesp.br, fpforesti@fc.unesp.br 
In the present paper, karyotypes and other chromosomal characteristics of specimens from two populations of Astyanax bockmanni from the same hydrographic basin (Barra Seca Stream and Campo Novo River) were studied to characterize the variations in heterochromatin revealed by C-banding and the phenotypes of the nucleolus organizer region (NOR) revealed by Ag-staining.

\section{Material and Methods}

Two Astyanax bockmanni populations were examined: 12 specimens ( 5 females and 7 males) collected from the Campo Novo River and 13 specimens (4 females, 3 males and 6 sex undefined individuals) from the Barra Seca Stream. Both sources belong to the Tietê River basin, São Paulo State, Brazil. The fishes were identified according to Vari \& Castro (2007), and the voucher specimens were stored in the fish collection from the Laboratório de Genética de Peixes, UNESP, Bauru, SP, Brazil.

Chromosomal preparations were obtained from gill and kidney tissues using the technique described by Foresti et al. (1993). Silver staining followed the technique of Howell \& Black (1980), and C-banding was performed according to Sumner (1972). Chromosomal morphology was determined by arm ratio as proposed by Levan et al. (1964), and the chromosomes were classified as metacentric (m), submetacentric (sm), subtelocentric (st), and acrocentric (a).

\section{Results}

The same diploid chromosome number, $2 \mathrm{n}=50$, was found for specimens examined from both populations. The karyotypes of specimens from the Barra Seca Stream and the Campo Novo River populations were composed of $6 \mathrm{~m}+14 \mathrm{sm}+14 \mathrm{st}+16$ a chromosomes, with a fundamental number (FN) of 84 (Fig. 1). Moreover, a pericentric inversion for the chromosomal pair No. 20 was detected in one individual from the Barra Seca Stream and was confirmed by C-banding (Fig. 2). No karyotype difference related to sex, and no B chromosomes were observed.

Constitutive heterochromatin patterns revealed by $\mathrm{C}$ banding showed heterochromatic blocks in the pericentromeric regions of most chromosomes and bands in the terminal regions of some chromosomes. Among the individuals of both populations, these positive terminal signals showed a high frequency of polymorphism (Fig. 3).

The Ag-impregnation revealed a high inter- and intraindividual variability for the NOR phenotypes in karyotypes of individuals from both populations, ranging from 1 to 8 terminal Ag-positive sites in several chromosomes. These polymorphisms were not only related to the number but also to the location of ribosomal cistrons because these sites were distributed on the long or short arm of several chromosomes. Sequential Ag-NOR staining and Cbanding demonstrated that some NORs were C-band positive (Fig. 4).

\section{Discussion}

The diploid chromosome number of $2 n=50$ described in the present study is in accordance with data previously reported for other populations of Astyanax bockmanni (Kavalco et al., 2009). Therefore, our results indicate a stable 2n for $A$. bockmanni in contrast to the species complexes $A$. fasciatus and $A$. scabripinnis that show variable diploid chromosome numbers in different individuals, some of which live in sympatry (Moreira-Filho \& Bertollo, 1991; Artoni et al., 2006).

Except for the invariable 2n, the karyotypes of specimens from the populations we studied and those analyzed by Kavalco et al. (2009) showed few differences. These differences were primarily in the number of $\mathrm{m}$, sm and $\mathrm{st}$ chromosomes. Such divergence can be responsible for the allopatric differentiation that occurs in some Astyanax species restricted to small tributaries and streams (Vicari et al., 2008b), and probably is due to the occurrence of nonRobertsonian chromosomal rearrangements such as centromeric shifts (Fig. 2), or extensive heterochromatin polymorphism, or both (Fig. 3).

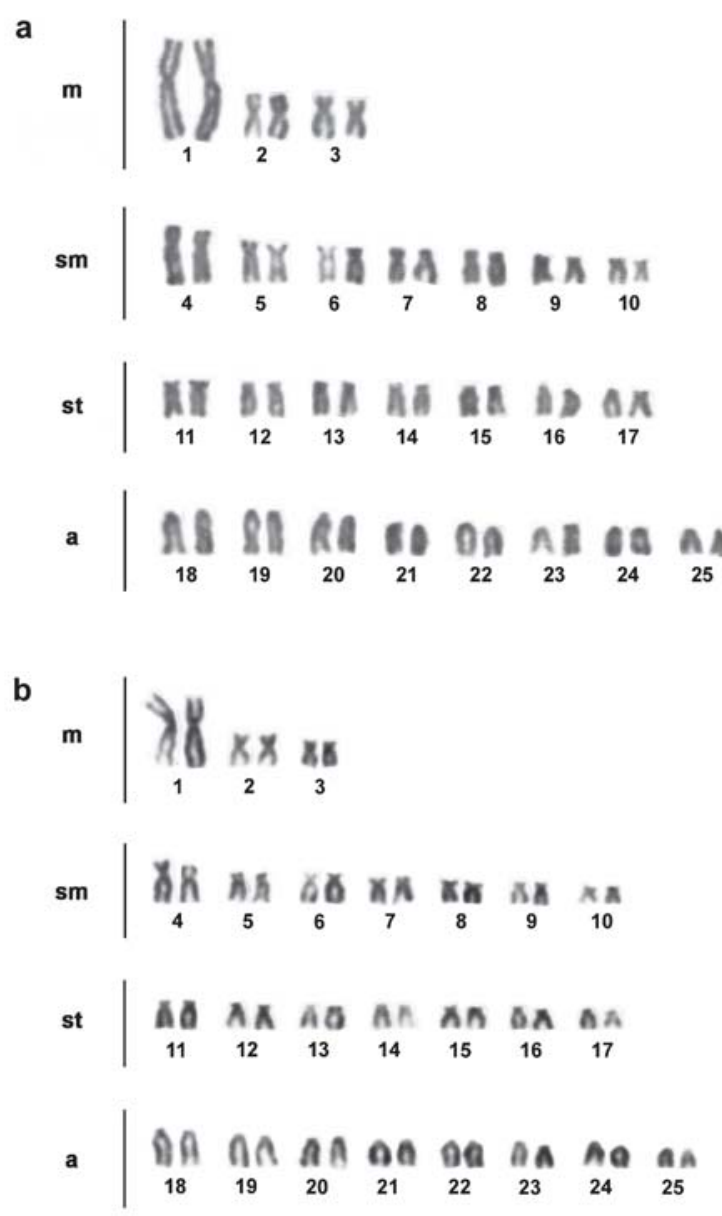

Fig. 1. Karyotypes of Astyanax bockmanni arranged from Giemsa-stained chromosomes. Specimens from Barra Seca Stream $(2 n=50)($ a $)$ and Campo Novo River $(2 n=50)($ b $)$. 

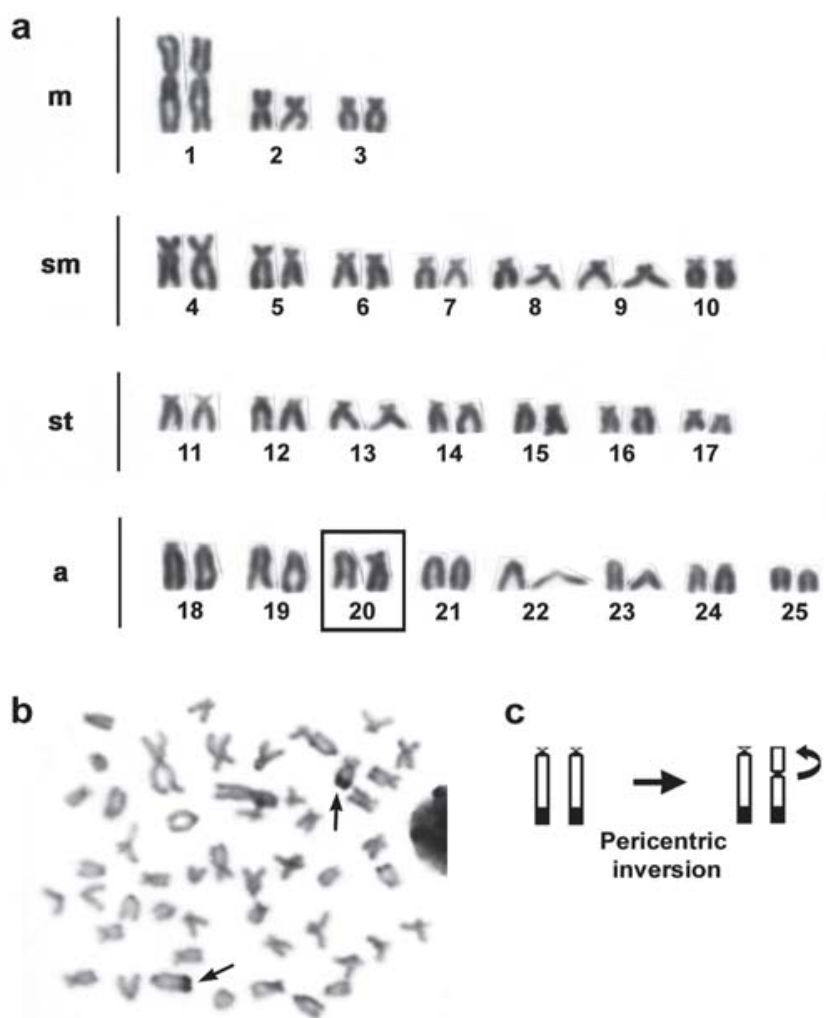

Fig. 2. (a) Karyotype arranged from Giemsa-stained chromosomes of an individual from the Barra Seca Stream, showing a pericentric inversion for the chromosomal pair No. 20. (b) C- banded metaphase indicating the chromosomes of pair No. 20. (c) Schematic representation showing the pericentric inversion.

Chromosome rearrangements due to inversions have been described in some fish groups (Centofante et al., 2002; Jorge $\&$ Moreira-Filho, 2004), with some cases involving the NORbearing chromosomes (Porto-Foresti et al., 2004; Mariotto et $a l ., 2009)$. Based on experimental crosses of farmed stocks of the salmonid Oncorhynchus mykiss, Porto-Foresti et al. (2004) suggested that a particular combination of chromosomes with inversions might be lethal in rainbow trout. For natural populations of neotropical fish, there are few descriptions of the biological effects related to this kind of chromosome polymorphism. A pericentric inversion of the first karyotype pair was detected in Serrasalmus spilopleura but without the structural homozygote (Centofante et al., 2002). Although this may be due to a sampling bias, such a situation seems to be comparable to our results where the homozygotes for the chromosomes with inversions were not found, suggesting that homozygosity might be a lethal genotype similar to the situation in O. mykiss (Porto-Foresti et al., 2004). Moreover, according to Mariotto et al. (2009), in the species Ancistrus cuiabae it would be possible to correlate differential fitness with distinct frequencies of cytotypes bearing chromosome inversions.

The distribution of constitutive heterochromatin patterns observed in the present study was similar to those described for karyotypes of different $A$. scabripinnis populations (Souza et al., 1996; Mantovani et al., 2000), with considerable heterochromatin variability on the distal regions of several chromosomes. These heterochromatic regions demonstrated a great inter-individual polymorphism, in contrast to the specimens studied by Kavalco et al. (2009) that did not possess such patterns.

Currently, several hypotheses have been proposed to explain the extensive polymorphism in the heterochromatin distribution in A. scabripinnis chromosomes, and our data corroborate some of them. Souza et al. (1996) suggested that the model proposed by Schweizer \& Loidl (1987), specifically the linear orientation of the anaphase opposite pole-directed centromeres during mitotic interphase, would permit heterochromatin transfers among sites equidistant from the centromeres of non-homologous chromosomes. According to Mantovani et al. (2000), heterochromatinization of euchromatic regions (King, 1980), unequal crossing-over (Smith, 1976), or amplification, accumulation and deletion (John, 1988), can also
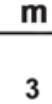

\section{$x|x|$}

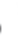

\section{III}

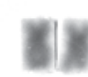

d
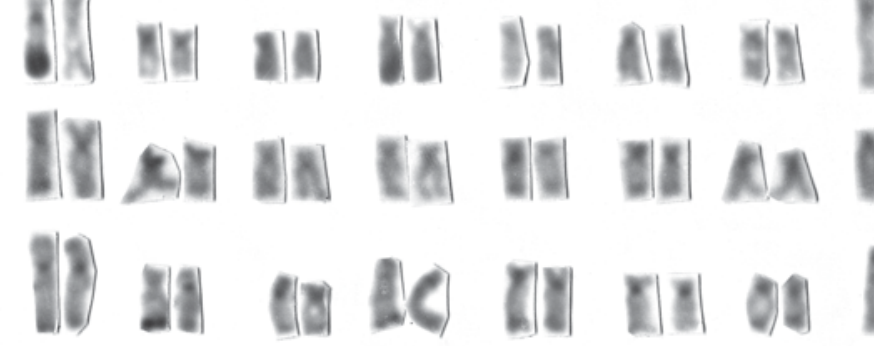
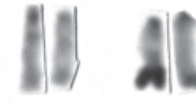

Fig. 3. Inter-individual polymorphisms of the heterochromatic blocks in Astyanax bockmanni from the Campo Novo River population. Each letter (a-d) represents a single individual. 

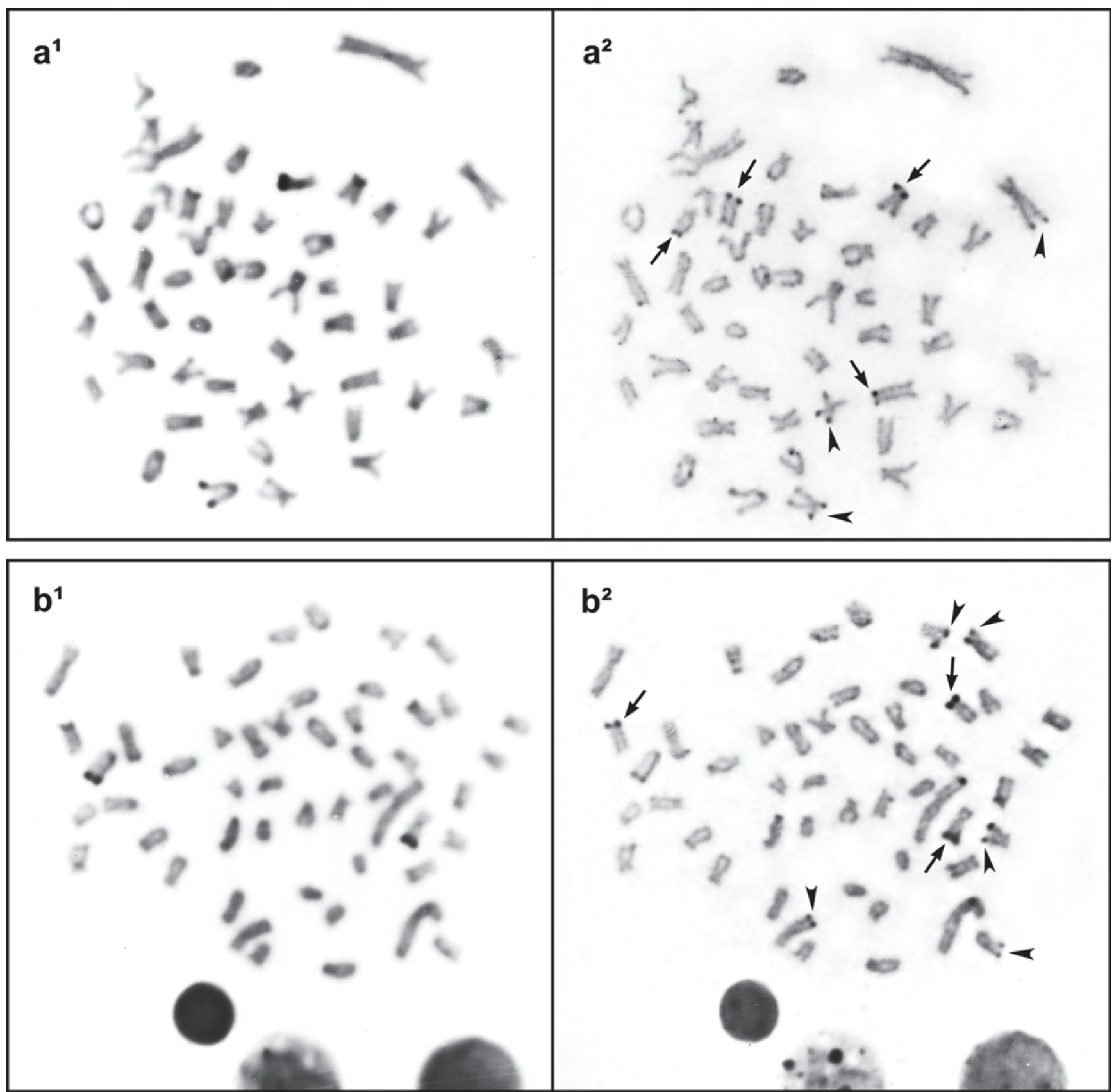

Fig. 4. Sequential C-banding $\left(\mathbf{a}^{\mathbf{1}}\right.$ and $\left.\mathbf{b}^{\mathbf{1}}\right)$ and Ag-NOR staining $\left(\mathbf{a}^{\mathbf{2}}\right.$ and $\left.\mathbf{b}^{\mathbf{2}}\right)$ in a specimen from the Campo Novo River, demonstrating the association between heterochromatin and NOR. In $\left(\mathbf{a}^{2}\right)$ and $\left(\mathbf{b}^{2}\right)$, arrows indicate the presence of heterochromatin/NOR association, and arrowheads show NORs not associated with heterochromatin.

be responsible for the high polymorphism in heterochromatin. Moreover, we cannot disregard the possible mechanism of genome invasion by transposable elements (Tafalla et al., 2006; Slotkin \& Martienssen, 2007).

Great variation in heterochromatic regions in the genomes of other Astyanax species has also been reported, and different groups have been revealed by the composition or structural organization of these regions (Souza et al., 1996; Mantovani et al., 2004; Abel et al., 2006). In some cases, such as A. janeiroensis and A. scabripinnis, there is still heterochromatin/rDNA (ribosomal DNA) association
(Mestriner et al., 2000; Vicari et al., 2008a). In these studies, a satellite DNA (As51) isolated from A scabripinnis (Mestriner et al., 2000) was used as the probe for in situ hybridization (FISH) to analyze the different heterochromatin classes in these species and NOR silencing in A.janeiroensis.

On the other hand, in $A$. bockmanni a different situation was reported (Kavalco et al., 2009). According to the authors, in FISH experiments the As51 satellite DNA probe did not hybridize to any genome region of this species. However, the absence of As51 satellite DNA in the genome of those individuals can be explained by the lack of major 
heterochromatic regions. Therefore, the analyses of other populations, using FISH with the As51 probe, will be necessary for better conclusions. In some populations with individuals showing a high degree of polymorphism of heterochromatin, as in the present study, the As51 DNA might hybridize to the genome of some of the specimens. Such a situation is found for the complex A. scabripinnis, which reveals populations with individuals bearing the As51 repetitive DNA on the chromosomes, as well as populations without the As51 satellite and major heterochromatic blocks (Abel et al., 2006).

Two structural classes of differently organized NORs were observed in the genomes of $A$. bockmanni individuals. Some active NORs were arranged in heterochromatic regions and some were not associated with heterochromatin (Fig. 4); apparently neither showed interference or divergence in their expression.

The NOR polymorphism observed in karyotypes of specimens from both populations has been a common characteristic among several Astyanax species (Ferro et al., 2001; Vicari et al., 2008a; Kavalco et al., 2009). This variation should be related to the NOR expression because the silver nitrate detects only active NORs (Howell, 1977; Jordan, 1987). The inter-individual polymorphism can also be explained by simple translocation events or, according to Schweizer \& Loidl (1987), by terminal regions exchanging genetic material due to their proximity within the interphase nucleus, promoted by chromosome ordering according to Rabl's model.

In conclusion, our data revealed a high degree of chromosome polymorphism in A. bockmanni. The populations from the Tietê River basin might be a good model to use for analyzing karyotype differentiation in this species. However, it is not possible to infer that karyotype variations of these populations have a direct relation to a speciation process or that this group constitutes a species complex. Despite our data indicating a chromosomal similarity to the species complex "A. scabripinnis", this latter group is very well studied and represents a taxon with historical inertia. In contrast, A. bockmanni was only recently described and may represent a truly valid taxon, with some degree of karyotype variation. This uncertainty shows that extensive studies of other populations are needed to better understand the karyotype diversification of this group.

\section{Acknowledgements}

The authors would like to thank Fernando C. P. D'Agosta and Ricardo M. C. Castro for the taxonomical identification. This work was supported by grants from Fundação de Amparo à Pesquisa do Estado de São Paulo (FAPESP) and Conselho Nacional de Desenvolvimento Científico e Tecnológico (CNPq).

\section{Literature Cited}

Abel, L. D. S., M. Mantovani \& O. Moreira-Filho. 2006. Chromosomal distribution of the As51 satellite DNA in two species complexes of the genus Astyanax (Pisces, Characidae). Genetics and Molecular Biology, 29(3): 448-452.
Artoni, R. F., O. A. Shibatta, M. C. Gross, C. H. Schneider, M. C. Almeida, M. R. Vicari \& L. A. C. Bertollo. 2006. Astyanax aff. fasciatus Cuvier, 1819 (Teleostei; Characidae): evidences of a species complex in the upper rio Tibagi Basin (Paraná, Brazil). Neotropical Ichthyology, 4(2): 197-202.

Bertaco, V. A. \& C. A. S. Lucena. 2006. Two new species of Astyanax (Ostariophysi: Characiformes: Characidae) from eastern Brazil, with a synopsis of the Astyanax scabripinnis species complex. Neotropical Ichthyology, 4(1): 53-60.

Buckup, P. A., N. A. Menezes \& M. S. Ghazzi. 2007. Catálogo das espécies de peixes de água doce do Brasil. Museu Nacional, Universidade Federal do Rio de Janeiro, Rio de Janeiro.

Centofante, L., J. I. R. Porto \& E. Feldberg. 2002. Chromosomal polymorphism in Serrasalmus spilopleura Kner, 1858 (Characidae, Serrasalminae) from central Amazon Basin. Caryologia, 55(1): 37-45.

Eigenmann, C. H. 1921. The American Characidae. Part 3. Memoirs of the Museum of Comparative Zoology, 43: 209-310.

Ferro, D. A. M., D. M. Neo, O. Moreira-Filho \& L. A. C. Bertollo. 2001. Nucleolar organizing regions, $18 \mathrm{~S}$ and $5 \mathrm{~S}$ rDNA in Astyanax scabripinnis (Pisces, Characidae): populations distribution and functional diversity. Genetica, 110: 55-62.

Foresti, F., C. Oliveira \& L. F. Almeida-Toledo. 1993. A method for chromosome preparations from large fish specimens using in vitro short-term treatment with colchicines. Experientia, 49: 810-813.

Hashimoto, D. T., V. R. Gonçalves, J. Bortolozzi, F. Foresti \& F. Porto-Foresti. 2008. First report of a B chromosome in a natural population of Astyanax altiparanae (Characiformes, Characidae). Genetics and Molecular Biology, 31(suppl): 275-278.

Howell, W. M. 1977. Visualization of ribosomal gene activity: silver stains proteins associated with rRNA transcribed from oocyte chromosomes. Chromosoma, 62: 361-367.

Howell, W. M. \& D. A. Black. 1980. Controlled silver-staining of nucleolus organizer regions with a protective colloidal developer: a 1-step method. Experientia, 36: 1014-1015.

John, B. 1988. The biology of heterochromatin. In: Verma, R.S. (Ed.). Heterochromatin: Molecular and Structural Aspects. Cambridge, Cambridge University Press.

Jordan, G. 1987. At the heart of the nucleolus. Nature, 329: 489-490.

Jorge, L. C. \& O. Moreira-Filho. 2004. Nucleolar organizer regions as markers of chromosomal polymorphism in Apareiodon affinis (Pisces, Parodontidae). Caryologia, 57(2): 195-199.

Kavalco, K. F., R. Pazza \& L. F. Almeida-Toledo. 2009. Astyanax bockmanni Vari and Castro, 2007: an ambiguous karyotype in the Astyanax genus. Genetica, 136(1): 135-139.

King, M. 1980. C-banding studies on Australian hylid frogs: secondary constriction structure and the concept of euchromatin transformation. Chromosoma, 80: 191-217.

Levan, A., K. Fredga \& A. A. Sandberg. 1964. Nomenclature for centromeric position on chromosomes. Hereditas, 52: 201-220.

Lima, F. C. T., L. R. Malabarba, P. A. Buckup, J. F. Pezzi da Silva, R. P. Vari, A. Harold, R. Benine, O. T. Oyakawa, C. S. Pavanelli, N. A. Menezes, C. A. S. Lucena, M. C. S. L. Malabarba, Z. M. S. Lucena, R. E. Reis, F. Langeani, L. Cassati \& V. A. Bertaco. 2003. Genera incertae sedis in Characidae. In: Reis, R. E., S. O. Kullander \& C. J. Ferraris (Eds.). Check List of the Freshwater Fishes of South and Central America. Porto Alegre, Edipucrs, 729p.

Mantovani, M., L. D. S. Abel, C. A. Mestriner \& O. Moreira-Filho. 2000. Accentuated polymorphism of heterochromatin and nucleolar organizer regions in Astyanax scabripinnis (Pisces, Characidae): tools for understanding karyotypic evolution. Genetica, 109: 161-168. 
Mantovani, M., L. D. S. Abel, C. A. Mestriner \& O. Moreira-Filho. 2004. Evidence of the differentiated structural arrangement of constitutive heterochromatin between two populations of Astyanax scabripinnis (Pisces, Characidae). Genetics and Molecular Biology, 27(4): 536-542.

Mariotto, S., L. Centofante, C. S. Miyazawa, L. A. C. Bertollo \& O. Moreira-Filho. 2009. Chromosome polymorphism in Ancistrus cuiabae Knaack, 1999 (Siluriformes: Loricariidae: Ancistrini). Neotropical Ichthyology, 7(4): 595-600.

Mestriner, C. A., P. M. Galetti Jr., S. R. Valentini, I. R. G. Ruiz, L. D. S. Abel, O. Moreira-Filho \& J. P. M. Camacho. 2000. Structural and functional evidence that a B chromosome in the characid fish Astyanax scabripinnis is an isochromosome. Heredity, 85: 1-9.

Mirande, J. M. 2009. Weighted parsimony phylogeny of the family Characidae (Teleostei: Characiformes). Cladistics, 25(6): 574-613.

Moreira-Filho, O. \& L. A. C. Bertollo. 1991. Astyanax scabripinnis (Pisces, Characidae): a species complex. Brazilian Journal of Genetics, 14(2): 331-357.

Nelson, J. S. 2006. Fishes of the World. John Wiley and Sons, Inc. New York, 601p.

Porto-Foresti, F., C. Oliveira, E. A. Gomes, Y. A. Tabata, M. G. Rigolino \& F. Foresti. 2004. A lethal effect associated with polymorphism of the NOR-bearing chromosomes in rainbow trout (Oncorhynchus mykiss). Genetics and Molecular Biology, 27: 51-54.

Schweizer, D. \& J. Loidl. 1987. A model for heterochromatin dispersion and the evolution of $\mathrm{C}$ band patterns. Chromosomes Today, 9: 61-74.
Slotkin, R. K. \& R. Martienssen. 2007. Transposable elements and the epigenetic regulation of the genome. Nature Reviews, 8 : 272-285.

Smith, G. P. 1976. Evolution of repeated DNA sequences by unequal crossover. Science, 191: 528-535.

Souza, I. L., O. Moreira-Filho \& P. M. Galetti Jr. 1996. Heterochromatin differentiations in the characid fish Astyanax scabripinnis. Brazilian Journal of Genetics, 19(3): 405-410.

Sumner, A. T. 1972. A simple technique for demonstrating centromeric heterochromatin. Experimental Cell Research, 74: 304-306.

Tafalla, C., A. Estepa \& J. M. Coll. 2006. Fish transposons and their potential use in aquaculture. Journal of Biotechnology, 123: 397-412.

Vari, R. P. \& R. M. C. Castro. 2007. New species of Astyanax (Ostariophysi: Characiformes: Characidae) from the Upper Rio Paraná System, Brazil. Copeia, 2007(1): 150-162.

Vicari, M. R., R. F. Artoni, O. Moreira-Filho \& L. A. C. Bertollo. 2008a. Colocalization of repetitive DNAs and silencing of major rRNA genes. A case report of the fish Astyanax janeiroensis. Cytogenetic and Genome Research, 122: 6772.

Vicari, M. R., R. B. Noleto, R. F. Artoni, O. Moreira-Filho \& L. A. C. Bertollo. 2008b. Comparative cytogenetics among species of the Astyanax scabripinnis complex. Evolutionary and biogeographical inferences. Genetics and Molecular Biology, 31: 173-179.

Accepted September 8, 2010 Published December 16, 2010 